\title{
THE ABUSE OF POWER BY “INDONESIAN LEADERS”
}

\author{
Nuah Perdamenta Tarigan \\ Character Building Development Center (CBDC), Bina Nusantara University \\ Jln. K.H. Syahdan No. 9, Palmerah, Jakarta Barat 11480 \\ nuah.tarigan@binus.ac.id, nuahptarigan1@gmail.com
}

\begin{abstract}
Indonesian leadership for some time suffered extraordinary shocks, the distrust of the leaders to make them not a role model anymore. The loss of integrity within the leader is very worrying for our state and nation; Indonesia's national security can be destroyed by it. It takes a very drastic change in the future to build Indonesia. Strong faith basis and professionalism coupled with a good work ethic will bring this nation to obtain a real leader, not worthy of their so-called leaders. Abuse of power that has been handed over to the leaders of the people are already too many and has touched every joint life of Indonesian society, there needs to be a consistent transformation of the nation's future, otherwise we will be destroyed, and the free fall in the abyss of evil. This paper will describe the current situation of Indonesia as well as concise and clear feedback about the solution, hopefully this can be determined for all of us to rebuild Indonesia.
\end{abstract}

Keywords: leadership, integrity, faith, abuse of power, transformation

\section{INTRODUCTION}

Leadership may be one of the broadest words to be defined. In simple words, leadership may refer to the activity of leading a group of people or an organization. However, actually, leadership has much deeper meaning than that. The definition stated above is undeniably true, but it is just the skindeep definition of leadership has different meanings. For example, according to Bass and Riggio (2006), leadership is defined as a form of persuasion, a power relation, the arts of inducing compliance, and also the exercise of influence. Northouse (2009) gives a different definition of leadership. To him, leadership is the moral use of power and that power occurs in relationships and should be used by leaders and followers to promote their collective goals which should be ethically good (Northouse, 2009).

Everything that is good has its own problems, including leadership. Leadership might face various major problems, and it will now be discussed as one of the leadership problems found most disturbing. People are not born as a leader, that trait is built over time and through experiences (Maxwell, 2009). However, there are often times when an individual who has not planted the seed of good leadership in her/him suddenly is given the privilege of being a leader. This sudden power received by that individual is often misused. This is why, a situation in which a leader does not act as how true leaders should be,is often be witnessed. The misuse of power by leaders is not only famous recently, it has been the issue of the world since a hundred years back. This is proven by the statement made by William Pitt, the former Prime Minister of Britain from 1766 to 1778, that unlimited power is apt to corrupt the minds of those who possess it (Hague, 2005).

Three concrete examples would now be given of well-known leaders which are known to abuse their powers. The first example that is the abuse of power by North Korea's Kim Jong Il. Kim Jong Il was the Supreme Leader of The Democratic People’s Republic of Korea since 1994 - 2011. He 
is very prominent for all the things he had done wrong to his country, but despite all of that, there is another troublesome abuse of power that he did, which was using his power to force women into being his personal concubines. Kim Jong Il has reportedly been known to kidnap women, including movie stars, who were further enslaved and treated as his personal concubines (Rank, 2013).

The second example that is about to discuss is Silvio Berlusconi, the former Prime Minister of Italy, who on May 2010 demanded the release of a young girl named Karima El Mahroug from the prison. Berlusconi, at that time, lied to the prison insisting that Karima was a relative of the Egyptian President Mubarak to quicken the release. After some time, it was revealed that Berlusconi has long been using his power to cover the fact that he paid El Mahroug continuosly to have a sexual relationship with him. To make things even worse, it was then discovered that this was not the first time that Berlusconi has been linked to younger women (Darraj, 2005).

The last example will be one of the most recent shocking fact about Akil Mochtar, the head of Constitutional Court. He has officially become the prime suspect of two bribery cases summed up to around Rp 3.000.000.000,- in various forms of currencies (Laisila, 2013). This is very ironic because Mochtar is supposed to be the Indonesia's highest country officials and to think that he has been trusted with a very big responsibility by Indonesian citizens is very heart-wrenching. It is expected that he should have hold close justice and honesty as the two most important values regarding his position.

Being a good leader will be much more easier when God is involved and through out making this paper, the Bible is also used as my references. These are some verses that is used for the basic foundations of my paper. Titus 1: 7-14: "For an overseer, as God's steward, must be above reproach. He must not be arrogant or quick-tempered or a drunkard or violent or greedy for gain, but hospitable, a lover of good, self-controlled, upright, holy, and disciplined. He must hold firm to the trustworthy word as taught, so that he may be able to give instruction in sound doctrine and also to rebuke those who contradict it. For there are many who are insubordinate, empty talkers and deceivers, especially those of the circumcision party. They must be silenced, since they are upsetting whole families by teaching for shameful gain what they ought not to teach". These verses basically explained to me how a great leader should be. God explicitly stated some of the characteristics a good leader should and should not have and this is a very strong foundation in building the act of leadership.

John 13: 13-17: "You call me Teacher and Lord, and you are right, for so I am. If I then, your Lord and Teacher, have washed your feet, you also ought to wash one another's feet. For I have given you an example, that you also should do just as I have done to you. Truly, truly, I say to you, a servant is not greater than his master, nor is a messenger greater than the one who sent him. If you know these things, blessed are you if you do them."These verses explained to all leaders that to be a good leader, one must follow the path of God, to serve others, to be a servant leader just like Himself, to put others' needs far above his or her own personal needs. These verses also force leaders to remember not to abuse their power.

Collossians 1:16: "For by him all things were created, in heaven and on earth, visible and invisible, whether thrones or dominions or rulers or authorities-all things were created through him and for him." This simple one line verse is a reminder of leaders that every privilege that they have, which now is the right to lead other people, is a blessing from God. Acknowledging that, a leader should always be thankful to God and should constantly seek for God's guidance. And of course, last but not least, to maintain an intimate relationship with God.

Some leaders are successful, some are not. Based on the theoretical framework, to be an effective leadership is a trait that can be learnt. All you need to do is understand the different approaches to leadership, so you can use te right approach in the right situation. There are three theoretical foundations that is usedwithin this paper. They are Trait Theory, Behavioral Theory, and Power and Influence Theory. 
Trait Theory (in Northouse, 2009) states that effective leaders share a number of common personality characteristics, or better referred as "traits" (insert reference). Some traits are very helpful when leading other, for example integrity, empathy and good decision-making skills. However, there is no specific combinations that will guarantee a leader's success. This theory helps me understand some of the essential trait a leader should have to be one of the great leaders. Nevertheless, these traits, no matter how many one possess, will mean nothing unless he or she has a great relationship with God.

Behavioral Theory focuses on how leaders behave. In the 1930s, Kurt Lewin developed a framework, in which leaders can be divided into three types: autocratic leaders (leaders who make decisions without consulting their teams), democratic leaders (leaders who allow the team to give input before making a decision), Laissez-faire leaders (leaders who will not interfere and who allows people in the team to make their own decisions). Through this theoretical framework, the different ways of how leaders behave and how that behavior will affect their performance can be learnt. This theory shows that God would want a democratic leader because after all, He taught us to put others ahead of us and it is believed that by listening to the follower's inputs, it is the very first step in placing others' needs before ours. (Northouse, 2009).

Power and influence theories - this theory of leadership take an entirely different approach these are based on the different ways that leaders use power and influence to get things done, and they look at the leadership styles that emerge as a result. The most famous theory is French and Raven's Five Forms of Power Theory, including: (1) Legitimate power: the belief that a leader has the formal right to make demands. (2) Reward power: a power that results from a leader's ability to compensate another for compliance. (3) Expert power: this is based on a leader's superior skill and knowledge. (4) Referent power: this is a result of a leader's perceived attractiveness, worthiness and right to respect from others. (5) Coercive power: the belief that a leader can punish others for noncompliance.This theory reminds me throughout this paper that a leader possess different kinds of power and these powers are part of the blessings from God and therefore should not be misuse and instead utilized for serving God (Northouse, 2009).

\section{METHODS}

The method that is applied is a qualitative method, where the qualitative method is a special research for objects that cannot be observed statistically or with quantification way, the qualitative research usually is used for observing social events, spiritual symptom, and sign process according to the non-positivism approach. For example, the people's lives, history, behavior, organization's functionalization, social movement, religion, or the relationship of human being. This research will produce descriptive data in the form of saying, writing, and behavior of observed people. Through the qualitative research, researcher can identify the subject and feel their daily experiences. In purpose of describing and analyzing phenomena, event, social activity, attitude, belief, perception, and human's thought - both as an individual and as part of a group. The qualitative research tends to be inductive. It means the researcher lets the problems appear from data or let open for interpretation, even though it takes time, eventually it will give more comprehensive opinion for the future.

\section{RESULTS AND DISCUSSIONS}

Basuki Tjahaja Purnama, or who was well-known as Ahok, is currently the vice governor of Jakarta. He becomes a media darling alongside Jokowi, the governor, because of the miracle that brought him to his position right now. Chinese has long been considered a minority in Indonesia and 
when he entered as one of Jakarta's vice governor candidate with Jokowi, it stirred up Jakarta a lot. This issue was exposed in a greater rate when he finally won the election and was officially elected as the vice governor of Jakarta. It has been known that a lot of Indonesian-born-Chinese and certain ethnics' citizens respected him a lot and was so grateful that he won the election.

Basuki Tjahaja Purnama was referred as one of the few candidates who did not use money as a mean to win the election. This information was taken for granted, without never really acknowledging how great a leader he is. This all changed when the internship program in Balai Kota was offered by my lecturer back in May 2013. After spending some time considering here and there, my curriculum vitae was sent to Balai Kota, attended the interview and was accepted as one of the interns. When coming for my internship, the first thing that is noticed are a number of elder people waiting in line. I then asked my superior what they were waiting for and then they came to ask for help. That was one of the service provided there. It was nice to see that Jakarta was willing to help those in need.

Ahok Center is a private office where Pak Ahok helps students who can not receive their report card because he or she has not paid for his or her tuition fee. Pak Ahok wisely uses his budget to help those people in need. There are a lot of personal things that he could buy for himself with that money and no one would complain, because it is his right after all. But instead, he knows better and he utilizes that power he possess to help other people, to make an impact to the environment, to be the salt and light of the world. Around two weeks along my internship, interns were invited for a lunch with Pak Ahok and had a very interesting conversation. It is not a surprise to know that there are a lot of people out there who hated him and who wanted him to fall. So, the very first thing that was asked was how he managed to stay calm, to not freak out acknowledging a handful of people hating him, and to avoid misusing his power. His answer was one of the most sayings that I remember up until now. Apparently, he always spend some time every single night to read the Bible, to maintain the relationship with God. He knows that God is the best place to turn to, to talk to, to consult to. Every time he found a verse that he thinks is best suited for his situation right now, he noted it in his mobile phone and keep it with him all the time, so whenever he is scared or angry, he will read it all over again and that feeling of being protected and cared for is fulfilled.

When we manage to be a good leader, there will always be another people who feel jealous, who want to be the cause of our fall. And at that time, while spending heaps of time being afraid, turning to God has to be done, to pray for strength because after all, God choose us to be a leader and that must mean something. It is believed that God would not give a problem that His disciple could not handle so anytime a leader face hardship, just know that God is standing beside you and He will never let you fall.

Leaders are known for their great power and this power can either be used to help others or to gain personally. The problem will arise when self-interest rules and leaders gain through the expense of their followers. To be able to choose how to utilize power might be one of the most ethical dilemmas a leader may face, but when they start listening to the voice of their hearts, when they have an intimate relationship with God and when they always decide something with God as its base, they no longer have to worry about making the wrong decision because God is always there to be their guidance (Barton, 2008).

No one is awarded as a leader without the help of God. Everyone turns into a leader through the process of God's calling and this calling has a structure. At first, as a starting point, God listens to the prayer of the oppressed. Further on, God sets the purpose of liberation. After that, the calling happens when God calls someone worthy enough to lead. This calling is often replied with an insecurity human response where human believes that he or she is not worthy enough and not capable of leading and answering God's calling. As soon as God hears this kind of response, that is when 
empowerment will happen, when God convinces human that He chooses that particular person for a reason.

To be a true leader in the eyes of God, the most important leadership mandate to be followed is to be the salt and light of the world. Salt, literally, refers to one of the most essential seasonings for food because without it, foods will be tasteless (Aikman-Smith, 2009). Adapted from its literal meaning, to be the salt of the world refers to the ability of a leader to give themselves truly for others, prioritizing social needs over his or her own, to empower people. Light, literally, refers to an electromagnetic radiation that can be detected by our eyes. Adapted from its literal meaning, to be the light of the world refers to the ability of a leader to enable his or her followers not to stay in darkness, disorientation, purposelessness, or ignorance.

There are so many examples of great leaders who successfully fulfill the mandate of being the salt and light of the world during his or her time as a leader. This time, five famous inspiring leaders will be shared. The first example is Mohandas Karamchand Gandhi, or who we all know as Mahatma Gandhi. He was initially born as an ordinary boy but since he was young, he had a strong determination to excel in anything that he did (Gandhi, 2012). He was famous for becoming one of the most important people in India. Through his policy of non-violence and protest through civil disobedience, he successfully led Indians to freedom against the colonial rule in 1947.

The second inspiring leader that is chosen to be discussed is George Washington. He was none other than the founding father of the United States of America, the leader of the American Revolution and the first president of US. Washington was known to have a very intimate relationship with God, he often visited the thicket to pray during the winter when his army was at Valley Forge (Thayer, 2000). Aside from that, he was referred as a true visionary since his vision has endured for more than 200 years. Leaders like Washington envision the future according to God's promises and envisioning is only possible through intimate relationship with God.

The third inspiring leader would be Nelson Mandela, the very first South African president elected in a fully democratic election. Mandela was not considered a great leader just because he was a president. Aside from being a president, he was the main player of the anti-apartheid movements in the country and unfortunately, sent into prison because of that (Stengel, 2010). This event, however, did not discourage Mandela and it was proven by how he continued devoting his life to uniting his country and, thank God, successfully managed to do so after the release of his almost-thirty-years-prisonsentence.

Bill Gates is chosen as my fourth inspiring leader. Bill Gates is the first name everyone might be thinking if people are talking about millionaires or billionaires. As the founder of Microsoft, Bill Gates might just use his power and money to have fun or for his personal advantage. But instead, he knows better and wisely determines that power and money is only the means of leadership whereas the end is to serve God. He serves God by being the salt and light of the world, helping people in need through Bill and Melinda Gates Foundation, which works on improving education in the US, fighting infectious diseases and improving the food supply all around the world (Aronson, 2009)

The last but definitely not the least inspiring leader is Abdurrahman Wahid, or who was better known as Gus Dur. He was the fourth president of Indonesia and he was very prominent for his struggle in bringing pluralism to this country (Barton, 2002). Indonesia used to be very close minded to those who had different religions besides Moslem or who was born in a different race, for example Chinese. Through Gus Dur's presidential term, he made a lot of change in Indonesia and one of the most famous amendments he made was when he made Chinese New Year as one of the official public holiday. At that point, he brought Indonesian-born-Chinese citizens to the same level as the other pure Indonesians and made them feel all worthy and respected. 


\section{CONCLUSIONS}

From what has been discussed in the text above, it can be seen that the leadership will find a very hard challenge, including the leader of the true and honest, nothing is easy and can run smoothly, the wrong actions of the leaders, in the Indonesian context, very much and had reams since many years ago, without any significant breakthrough, we only arrive at the skin level and discourse, but do not penetrate deeply into. Log into our hearts very deep, as the conscience of man created by God Almighty, the most beloved creations! Ought we were created to be useful for others, including the creatures and even the weakest of society, which often does not happen. Jokowi (JokoWidodo) and Ahok (Basuki Tjahaya Purnama) is the antithesis to all this, let us wake up a better Indonesia in the future, not Indonesia, which slumped back.Indonesian dignified and civilized, humanize and build a human from all walks of life regardless of the origin of feathers and, backgrounds, religions and races, undoubtedly Indonesia will be more advanced and civilized and fair, prosperous in the near future.

\section{REFERENCES}

Aikman-Smith, V. (2009). Salt: Cooking with the world's favorite seasoning. London: Ryland Peters \& Small.

Aronson, M. (2009). Bill Gates: a Twentieth-Century Life. New York, NY: Viking Juvenile.

Barton, G. (2002). Gus Dur: the Authorized Biography of Abdurrahman Wahid. Jakarta: Equinox Publishing.

Barton, R. H. (2008). Strengthening the Soul of Your Leadership: Seeking God in the Crucible of Ministry. Downers Grove, IL: IVP Books.

Bass, B. M., Riggio, R. E. (2006). Transformational Leadership ( $2^{\text {nd }}$ ed). Mahwah, NJ: $\quad$ Psychology Press.

Darraj, S. M. (2005). Silvio Berlusconi. Philadelphia: Chelsea House Pub (L).

Gandhi, M. K. (2012). Autobiography: the Story of My Experiments with Truth. CreateSpace Independent Publishing Platform.

Hague, W. (2005). William Pittthe Younger (1st American ed.). New York: Knopf.

Laisila, L. (2013, 4 Oct). Ketua Mahkamah Konstitusi Indonesia Resmi Jadi Tersangka Korupsi. Retrieved October 25 2013 from http://www.radioaustralia.net.au/indonesian/2013-1003/ketua-mahkamah-konstitusi-indonesia-resmi-jadi-tersangka-korupsi/1199912

Maxwell, J. C. (2009). Leadership 101. Chicago: Christian Audio.

Northouse, P. G. (2009). Leadership: Theory and Practice of Leadership (5 ${ }^{\text {th }}$ ed). Thousand Oaks: SAGE.

Rank, M. (2013). History's Most Insane Rulers: Lunatics, Eccentrics, and Megalomaniacs from Emper. CreateSpace Independent Publishing Platform. 
Stengel, R. (2010). Mandela's Way: Lessons on Life, Love, and Courage. New York: Crown Archetype.

Thayer, W. M. (2000). A Biography of George Washington: the Patriot President (sons of Liberty Series). Beka Book. 